Ankara University,

Faculty of Political Science

The Turkish Yearbook of

International Relations,

Volume 45 (2014), p. 1 - 22

\title{
Understanding of the Turkish Constitutional Court Regarding Unitary State
}

\author{
Deniz Polat ${ }^{*}$
}

\begin{abstract}
The jurisprudence of the Turkish Constitutional Court on the concept of the unitary state has been a controversial issue in Turkey for a long time. The 1982 Constitution does not refer to the concept of 'unitary' or 'unitary state'. Instead, it refers to the principle of the 'indivisible integrity of the state with its territory and nation' in many articles. The Turkish Constitutional Court interprets this principle of the territorial and national integrity of the state in a manner to protect the unitary nature of the state as well. Since the references to the principle of the unitary state may frequently be seen in political party dissolution cases and some other annulment actions, these cases will be the scope of this article. Accordingly, the understanding of the Court regarding this issue will be considered within the principles that set forth by the European Court of Human Rights, the Venice Commission, and the European Charter of Local Self-Government.
\end{abstract}

* Research Assistant, Department of Constitutional Law, Ankara University School of Law. This article is an extended version of a previous paper that peresented at the II. Turkish-Italian Seminer of Constitutional Law in Bologna/Italy, on 25 $5^{\text {th }}$ September 2014. 


\section{Introduction}

This article deals with the Turkish Constitutional Court's (TCC) interpretation of the concept of 'unitary state'. Then, the research question should be 'what is a unitary state according to the TCC?'. Accordingly, first I will define the concept of the unitary state and give a brief constitutional history of it. Finally I will argue the TCC's understanding of the unitary state through the cases.

A unitary state is a type of a political organization deeply rooted in the French Revolution. This is why, the principle of territorial and national integrity of a state also takes its source from the centralist French state model ${ }^{1}$. Since the state types are identified by focusing on the relationships between central and local administrations, a unitary state is defined as the habitual exercise of supreme legislative authority by one central power ${ }^{2}$. Therefore, in a unitary state there is only a single central government that the whole legislative, executive, and judicial authority belongs to. Surely, this central government may delegate some of these authorities to local ones, but the crux of the matter is that these local authorizations may be established or abolished only by the central power ${ }^{3}$. In other words, powers of

1 C. F. Strong, A History of Modern Political Constitutions: An Introduction to the Comparative Study of Their History and Existing Form, G. P. Putnom's Sons, New York 1963, at 97.

$2 I d$., at 80 . The other two state types would be the federal state and the regional state. A federal state is defined as a distinction of powers between the central/federal authority and the authorities of the units forming the federation. On the other hand, in a regional state - as a hybrid model - a real measure of local autonomy is recognized to local units in order to relieve the central government of some of its multifarious functions. See, Arend Lijphart, Patterns of Democracy: Government Forms and Performance in Thirty-Six Countries, Yale University Press, 1999, at 186; Oktay Uygun, Federal Devlet (Federal State), XII Levha Yayıncll1k, 3rd Edition, İstanbul 2007, at 79-80; Montserrat Guibernau, Nations Without States: Political Communities In a Global Age, Polity Press, 1999, at 50-59; Strong, supra note 1, at 64.

3 Selin Esen, Ulus-Devlet Modelleri ve İspanya Örneği (Nation State Models and Spain for an Example) Yayınlanmamış Doktora Tezi (Unpublished Phd Thesis), Ankara 2001, at 22. 
the local units may be broadened and narrowed by the central government. This means that there is no semi-sovereign legislative, executive, or judicial bodies.

In a unitary state, political power - whether internal or external should only be used by the central government due to the singleness of sovereignty. According to this, internal sovereignty may be defined as the supremacy of a person or body of persons in the state over the individuals or associations of individuals within the area of its jurisdiction, and external sovereignty as the absolute independence of one state as a whole with reference to all other states ${ }^{4}$. Essentially, internal sovereignty determines the type of the state $^{5}$. Concentration or dispersion of the political power specifies the difference between a unitary, a federal or a regional state. The nation and the territory of the state are other two indivisible elements in a unitary state. Every nation is under the same sovereignty without making any discrimination based on language, religion, or ethnicity. Administrative units can be established, but they could not have legislative or judicial powers, and separation of a part of the territory from the state is not allowed.

\section{An Overview of the Concept of the Unitary State in Turkish Constitutional History}

The type of a state is related to institutional preferences. Since these preferences may be formed by the historical experience of a society, the Ottoman Empire should be the starting point in examining the development of the unitary state. Therefore, the research will begin with the 1876 Constitution (Kanun-i Esasi) which was considered the first Constitution of the Ottoman Empire - and will continue chronologically with the 1909 amendments of the 1876 Constitution, the 1921 Constitution, the 1924 Constitution, the 1961 Constitution, and finally with the current 1982 Constitution.

4 Strong, supra note 1 , at 80.

5 Esen, supra note 3, at 23. 
According to the 1876 Constitution, the state had indivisible integrity with its territory 6 . Besides, the other two requirements of a unitary state type were recognized. These are the singleness of the legislative ${ }^{7}$ and of the executive power ${ }^{8}$. In addition to that, powers of the Sultan were widely identified under this Constitution. In principle, these provisions can be seen as a reference to the unitary state type. However, the 1876 Constitution stated that a group of provinces and religious communities had privileges ${ }^{9}$. This is why, under the Constitution of 1876, the Ottoman Empire may not be defined as a unitary state, due to these exceptions ${ }^{10}$.

The 1909 amendments of the 1876 Constitution provided additional fundamental rights and freedoms. The scope of the powers of the Sultan were relatively curtailed, and the 'national sovereignty' through the legislative power became the focal point ${ }^{11}$. This was a movement towards a more centralist state type but still, there was no clear reference to the unitary state.

After the collapse of the Ottoman Empire, the 1921 Constitution (Teşkilât- $\iota$ Esasiye Kanunu) established a new state, the so called the Turkish Republic. With this Constitution, Turkey took a huge stride in its constitutional history.

6 The 1876 Constitution (Kanun-i Esasi), art. 1. See, Şeref Gözübüyük \& Suna Kili, Türk. Anayasa Metinleri (Turkish Constitutional Documents), $2^{\text {nd }}$ Edition, AÜSBF Yayınlar1, No: 496, Ankara 1982, at 27. For the English version of the 1876 Constitution See, http://genckaya.bilkent. edu.tr/documents1.html, Access Date: 15.09.2014.

7 See, The 1876 Constitution, art. 53.

8 See, The 1876 Constitution, art. 7.

9 See, The 1876 Constitution, art. 1, 7, 11, 108.

10 For an opinion on defining the Ottoman Empire as a 'regional state', based on the 1876 Constitution, see, Atilla Nalbant, Uniter Devlet: Bölgesellesmeden Küresellesmeye (Unitary State: From Territorialization to Globalization), 2nd Edition, XII Levha Yayıncillk, İstanbul 2012, at 147.

11 Cem Eroğul, "1908 Devrimi'ni İzleyen Anayasa Değişiklikleri (The Following Constitutional Amendments After the 1908 Revolution)", 100. Yllinda Jön Türk Devrimi, Ed: Sina Akşin, Sarp Balc1, Barış Ünlü, Türkiye İş Bankası Kültür Yayınları, İstanbul 2010, at137; Bülent Tanör, OsmanlvTürk Anayasal Gelismeleri (Ottoman-Turkish Constitutional Developments), $8^{\text {th }}$ Edition, YKY, İstanbul 2002, at 220. 


\section{Deniz Polat}

Understanding of the Turkish Constitutional Court

Regarding Unitary State

The 1921 Constitution explicitly utilized the term of autonomy (muhtariyet) and referred to the 'county and township councils (vilayet ve nahiye şuralart)' for the first time. Actually, the 1921 Constitution was the only constitution that regulated the local governments in such a detailed manner in Turkish constitutional history $^{12}$. On the other hand, this autonomy was only given to administrative authorities to constitute a much more efficient administrative management, but without any political purpose ${ }^{13}$. Additionally, the expression of the Grand National Assembly of Turkey (TBMM) is the only representative of the nation' demonstrated that, political decisions regarding the future of the nation must be taken only by Parliament ${ }^{14}$. Since the legislative and the executive power belongs to the central government, the state type seems to be a unitary state in the 1921 Constitution 15 . In spite of this, because of the local administration councils, there was a general impression that administrative structure was based on local governments ${ }^{16}$. Counties had the authorities on the fields of health, education, public works, finance, and agriculture ${ }^{17}$. Even townships had the financial and the judicial authorities ${ }^{18}$. However, local executive powers had given to local governments in an administrative sense to meet people's needs more effectively and functionally. In other words, local governments did not have a law-making capacity. As a result, we may not assume that the 1921 Constitution envisaged a regional or a federal state type. Nonetheless, we may argue that the 1921 Constitution embraced the unitary state model within the decentralized administrative bodies.

12 Ergun Özbudun, 1921 Anayasası (The 1921 Constitution), Atatürk Kültür, Dil ve Tarih Yüksek Kurumu Atatürk Araştırma Merkezi, Ankara 1992, at 43.

13 Tanör, supra note 11, at 257.

14 See, The 1921 Constitution, art. 2; See, Gözübüyük \& Kili, supra note 11, at $99-100$.

15 See, The 1921 Constitution, art. 2.

16 Nalbant, supra note 10, at 184, 190.

17 See, The 1921 Constitution, art. 11.

18 See, The 1921 Constitution, art. 20. 
These comprehensive provisions of the 1921 Constitution on local governments had never been enforced ${ }^{19}$. Under the extraordinary circumstances of the National Liberation War, the 1921 Constitution did not include a section on fundamental rights and freedoms and regulated only the basic principles regarding the organization of the state 20 . This is why, the necessity of a new constitution was born.

The 1924 Constitution essentially reflected an individualistliberal philosophy ${ }^{21}$. Just as in the 1921 Constitution, the 1924 Constitution stated that the Turkish nation wields its own sovereignty through the TBMM, and the national sovereignty was the core of the system as well ${ }^{22}$. The main difference between the former constitutions and the 1924 Constitution was that the 1924 Constitution did not include any concept like autonomy or self governance. Then, we may consider that the 1924 Constitution represented a more centralist unitary state model ${ }^{23}$. However, this Constitution did not refer to the unitary state per se.

The 1961 Constitution does not refer to the concept of 'unitary' or 'unitary state'. Instead, it refers to the principle of the 'indivisible integrity of the state with its territory and nation' in many articles $^{24}$. This became a legal regulation with the 1961 Constitution, for the first time ${ }^{25}$. The 1982 Constitution does not refer to the 'unitary state' phrase as well, but repeats this principle verbatim in the preamble and in several other articles,

19 Tanör, supra note 11, at 266.

20 On the issue of fundamental rights and freedoms, the 1876 Constitution was considered to be in force. See, Bülent Tanör, İki Anayasa (Two Constitutions), $3^{\text {rd }}$ Edition, Beta, İstanbul 1994, at 128.

21 Tanör, supra note 20, at 129.

22 The 1924 Constitution, art. 3, 4.

23 Even during the discussions on the draft of the 1924 Constitution, federation proposals took place, but were rejected after all. See, Şeref Gözübüyük \& Zekayi Sezgin, 1924 Anayasası Hakkindaki Meclis Göruismeleri (Debates in the Parliament on 1924 Constitution), AÜSBF Yayınları, Ankara 1957, at 450.

24 See, e. g. 1961 Constitution, art. 3, 11, 22, 25, 28, 45, 57, 121, 136.

25 The 1961 Constitution, art. 3. 


\section{Deniz Polat}

Understanding of the Turkish Constitutional Court

Regarding Unitary State

moreover, as an unamendable provision26. Furthermore, the 1982 Constitution indicates that rights and freedoms cannot be abused in order to alter this principle, just as the 1961 Constitution does $^{27}$. Therefore, we may say that, the 1982 Constitution considers this principle as a fundamental of the constitutional system. As will be seen below, the TCC also reads this principle within the mentioned perspective of the current Constitution.

\section{Jurisprudence of the Turkish Constitutional Court on the Unitary State}

The Turkish Constitutional Court (TCC) interprets the principle of the indivisible integrity of the state with its territory and nation in a manner to protect the unitary nature of the state. Since the references to the concept of unitary state may frequently be seen in political party dissolution cases in Turkey, these judgments of the TCC are going to be the core of this study.

According to the TCC, the territorial and national integrity of the state is a limitation of the right to found a political party, a legal ground to ban a political party, and also a preference of a state type. Activities of the political parties may be banned under the circumstances listed in the 1982 Constitution ${ }^{28}$. Any conflict with the principles that signified in Article 68(4), such as the independence of the state or the indivisible integrity of the state with its territory and nation, are one of these. As a matter of fact, thirteen political parties since the 1982 Constitution came into force and two in the era of 1961 Constitution dissolved by the

26 See, e. g. 1982 Constitution, art. 3, 5, 14, 26, 28, 58, 81, 103, 118, 122, 130. According to the article 3 and the article 4 of the Constitution, the Turkish state is an indivisible entity with its territory and nation, and amendment of this provision is prohibited.

27 The 1961 Constitution, art. 11; The 1982 Constitution, art. 14; also refers in art. 28, 58, 81, 103 and 130.

28 The 1982 Constitution, art. 68, 69. 
TCC, based on the violation of the principle of territorial and national integrity of the state 29 .

29 Here is the list of banned political parties by the TCC, based on the violation of the principle of indivisible integrity of the state with its territory and nation:

United Communist Party of Turkey (TBKP), Case No.1990/1 (Political Party Dissolution), Decision No. 1991/1, (TCC, 16.7.1991), published in Official Gazette 21125, 28.1.1992.

Socialist Party (SP), Case No.1991/2 (Political Party Dissolution), Decision No. 1992/1, (TCC, 10.7.1992) published in Official Gazette 21386, 25.10.1992.

People's Labour Party (HEP), Case No.1992/1 (Political Party Dissolution), Decision No. 1993/1, (TCC, 14.7.1993), published in Official Gazette 21672, 18.8.1993.

Freedom and Democracy Party (OZDEP), Case No.1993/1 (Political Party Dissolution), Decision No. 1993/2, (TCC, 23.11.1993), published in Official Gazette 21849, 14.2.1994.

Socialist Turkey Party (STP), Case No.1993/2 (Political Party Dissolution), Decision No. 1993/3, (TCC, 30.11.1993), published in Official Gazette 22016, 9.8.1994.

Democracy Party (DEP), Case No.1993/3 (Political Party Dissolution), Decision No. 1994/2, (TCC, 16.6.1994), published in Official Gazette 21976, 30.6.1994.

Socialist Unity Party (SBP), Case No.1993/4 (Political Party Dissolution), Decision No. 1995/1, (TCC, 19.7.1995), published in Official Gazette 23266, 22.2.1998.

Democracy and Change Party (DDP), Case No.1995/1 (Political Party Dissolution), Decision No. 1996/1, (TCC, 19.3.1996), published in Official Gazette 23149, 23.10.1997.

Labour Party (EMEP), Case No.1996/1 (Political Party Dissolution), Decision No. 1997/1, (TCC, 14.2.1997,) published in Official Gazette 23384, 26.6.1998.

Democratic Mass Party (DKP), Case No.1997/2 (Political Party Dissolution), Decision No. 1999/1, (TCC, 26.2.1999), published in Official Gazette 24591, 22.11.2001.

People's Democracy Party (HADEP), Case No.1999/1 (Political Party Dissolution), Decision No. 2003/1, (TCC, 13.3.2003), published in Official Gazette 25173, 19.7.2003.

Rights and Freedoms Party (Hak-Par), Case No. 2002/1(Political Party Dissolution), Decision No. 2008/1 (TCC, 29.01.2008), published in Official Gazette 26923, 1.07.2008. 


\section{Deniz Polat}

Understanding of the Turkish Constitutional Court

Along with the Constitution, the Political Parties Act of 1983 (PPA) specifies the bans and restrictions on political parties such as, political parties are banned from claiming the existence of national, religious, cultural, racial, or linguistic minorities in the country; aiming and acting to destroy national unity through creating minorities in the name of protection, development and dissemination of other languages and cultures aside from Turkish language and culture, using other languages than Turkish and intending and acting for regionalism or racism ${ }^{30}$. As listed in this Act, political parties are banned from mostly claiming any kind of minorities or acting for regionalism ${ }^{31}$. Then, we may say that the PPA embodies the prohibitions in the Constitution and the principle of territorial and national integrity of the state as a rigid central version of a unitary state. The controversial issue is that the TCC prefers to adopt this narrow conceptualization of the PPA instead of interpreting the principle widely ${ }^{32}$.

Democratic Society Party (DTP), Case No.2007/1 (Political Party Dissolution), Decision No. 2009/4, (TCC, 12.11.2009), published in Official Gazette 27449, 31.12.2009.

Labour Party of Turkey (TIP), Case No.1971/3 (Political Party Dissolution), Decision No. 1971/3, (TCC, 20.7.1971), published in Official Gazette 14064, 6.11.1972.

Labour Party of Turkey (TEP), Case No.1979/1 (Political Party Dissolution), Decision No. 1980/1, (TCC, 8.5.1980), published in Official Gazette 17059, 26.7.1980.

See, Hüseyin Murat Işı, Anayasa Mabkemesi Kararlarnda Devletin Resmi Ideolojisi: Siyasi Parti Kapatma Kararlarmm İcerik Analizi (Formal Ideology of the State Within the Judgements of the Constitutional Court: An Analyse of Political Party Dissolution Cases), Adalet Yayınevi, Ankara 2012, at xv1-xv11.

30 The Political Parties Act, art. 81, 82.

31 The Political Parties Act, art. 81-83.

32 For a similar approach, see Merih Öden, Türk Anayasa Hukukunda Siyasi Partilerin Anayasaya Aykem Eylemleri Nedeniyle Kapatulmalarn (Closures In Constitutional Law For Activities of Political Parties Contrary to the Constitution), Yetkin Yayınlar1, Ankara 2003, at 120; Bülent Tanör \& Necmi Yüzbaşıoğlu, 1982 Anayasasina Göre Türk Anayasa Hukuku (Turkish Constitutional Law According to the 1982 Constitution), 3 $3^{\text {rd }}$ Edition, YKY, 
We may discuss the principle of the indivisible integrity of the state with its territory and nation by separating into two parts: 'the territorial integrity' of the state and 'the national integrity' of the state. The TCC deals with the territorial integrity of the state as an extension of 'singleness of the state', which the PPA refers in Article 80. Indeed the TCC states that, the meaning of the territorial integrity of the state is equal to the principle of unitary state type. The Court sees federalism as a tool of ethnic separatism and reads the unitary state type as the only way to provide the national solidarity in Turkey ${ }^{33}$. As a result of this interpretation, the Court concludes that the territorial integrity of the state does not permit federal or any kind of regional types of government ${ }^{34}$. Therefore, political parties may not defend or even suggest these kinds of state types in their statutes or programs. According to the Court, the statements manifested in the party program may give rise to the dissolution of the political party when they are explicitly contrary to the Constitution ${ }^{35}$. We may consider that, according to the TCC, defending a different state type is a natural cause to the violation of the principle of territorial integrity. This is why, according to the Court, political activities that aim to divide the state or change the state type should not be considered as an exercise of rights and freedoms ${ }^{36}$.

İstanbul 2002, at 111-112; İbrahim Kaboğlu, Örgürlïkler Hukuku (Law of Liberties), $6^{\text {th }}$ Edition, İmge, Ankara 2002, at 434-435.

33 Oktay Uygun, "Üniter ve Federal Devlet Açısından Egemenliğin Bölünmezliği İlkesi (Indivisibility of the Sovereignty Regarding to the Unitary and the Fedaral State)", Cumburiyetin 75. Yal Armağan, İÜ Yayın1, İstanbul 1999, at 409.

34 See, Democracy Party (DEP), Case No.1993/3, Decision No. 1994/2; Socialist Party (SP), Case No. 1991/2, Decision No. 1992/1.

35 See, Bülent Algan, "Dissolution of Political Parties by the Constitutional Court in Turkey: An Everlasting Conflict Between the Court and the Parliament?", AÜHFD, Vol. 60, No. 4, 2011, at 819. See, Socialist Party, No. 1991/2, Decision No. 1992/1; Socialist Union Party, Case No. 1993/4, Decision No. 1995/1, Labour Party, Case No. 1996/1, Decision No. 1997/1.

36 See, Democracy Party (DEP), Decision No. 1994/2; Democracy and Change Party (DDP), Decision No. 1996/1; People's Democracy Party (HADEP), Case No. 1999/1, Decision No. 2003/1 (TCC, 13.03.2003), published in Official Gazette 25173, 19.07.2003. 


\section{Deniz Polat}

Understanding of the Turkish Constitutional Court 11 Regarding Unitary State

However, defending federalism - as long as defending in accordance with the democratic methods - should be regarded as in the context of freedom of expression ${ }^{37}$. Besides, we may argue that the principle of the indivisible territorial integrity of the state refers to the nation-state. In a nation-state, the unitary state is one of the state types along with federalism and regionalism. Since the Constitution does not explicitly prohibits some of these nation-state types, the TCC's interpretation based on the PPA may be considered to be unconstitutional ${ }^{38}$.

The TCC interprets the 'national integrity of the state' as restrictively as the territorial integrity. Accordingly, TCC states that recognizing any kind of minorities depending on race or language difference will be a violation of the territorial and the national integrity of the state. Then, defending the existence of minorities and their rights and freedoms should be regarded as an aim to disunify the state ${ }^{39}$.

According to the TCC "to attempt separatism, to create minorities within the country as 'Kurdish nation' separate from the 'Turkish

37 Ekrem Ali Akartürk, Türk Hukukunda Siyasal Parti Yasaklar (The Probibitions of Political Parties in Turkish Law), Yeditepe Üniversitesi Hukuk Fakültesi Yayınları, İstanbul, 2008, at. 197.

38 Selin Esen, "How Influential Are The Standards of The European Court of Human Rights on The Turkish Constitutional System In Banning Political Parties?", Ankara Law Review, Vol. 9, No. 2, Winter 2012, at 143. For a similar approach, see Ergun Özbudun, "Party Prohibiton Cases: Different Approaches By The Turkish Constitutional Court and The European Court of Human Rights", Democratization, Vol. 17, No. 1, February 2010, at 130 and see Zühtü Aslan, "Conflicting Paradigms: Political Rights in the Turkish Constitutional Court", Critical Middle Eastern Studies, Vol. 11, No. 1, Spring 2002, at 13.

39 See, People's Labour Party (HEP), Case No. 1992/1, Decision 1993/1; Freedom and Democracy Party (OZDEP), Case No. 1993/1, Decision No. 1993/2; Democracy and Change Party (DDP), Case No. 1995/1, Decision No. 1996/1; Labour Party (EMEP), Case No. 1996/1, Decision No. 1997/1; United Communist Party of Turkey (TBKP), Case No. 1990/1, Decision No.1991/1. As a debatable judgement, in People's Labour Party case, TCC states that federalism cannot be accepted because there is only one nation in Turkey. 
nation' and to defend the establishment of a Kurdish-Turkish federation or self-determination for any other so-called minorities through their statutes and programs and/or their activities" are the legal grounds to ban a political party ${ }^{40}$. The Court also stresses that while the Lausanne Peace Treaty listing all minorities within the boundaries of Turkey, no mention of the Kurdish nation was made, and for this reason they were not accepted as a minority ${ }^{41}$. Additionally, the principle of territorial and national integrity of the state has been considered as mandatory to sustain and protect the existence of the state. That's because, according to the TCC, the Constitution prevents any kind of demand against Turkish nationalism, such as having education in the Kurdish language or development and dissemination of another native language or culture ${ }^{42}$.

As we know so far, the TCC does not accept the existence of minorities, yet it considers the claim of existence of any minority as a violation of the national integrity as well as the unitary state. Even in the past, a political party stated the voluntary solidarity of Turkish and Kurdish nation' in its political party program, and the Court perceived this as an intendment of creating feelings of hostility and separatism ${ }^{43}$. According to the Court, 'following a tradition' is an ordinary thing to do in everyday life and it's

40 See, Socialist Party (SP), Decision 1992/1; Freedom and Democracy Party (OZDEP), Decision No. 1993/2; Democracy Party (DEP), Case No. 1993/3, Decision No. 1994/2; United Communist Party of Turkey (TBKP), Decision 1991/1; People's Labour Party (HEP), Decision 1993/1.

41 See, Labour Party of Turkey (TIP), Case no. 1971/3, (Political Party Dissolution), Decision No. 1971/3, (TCC, 20.07.1971), published in Official Gazette 14064, 6.1.1972. TCC reinforces its judgement by using the argument that there is no another international document which describes the minorities in Turkey, and because of that, the Court should be stick to whatever the Lausanne Peace Treaty envisages.

42 See, Labour Party of Turkey (TEP), Case No.1979/1, (Political Party Dissolution), Decision No. 1980/1,(TCC, 8.5.1980), published in Official Gazette 17059, 26.7.1980; Socialist Party (SP), Decision 1992/1; Freedom and Democracy Party (OZDEP), Decision No. 1993/2; Democracy Party (DEP), Decision No. 1994/2.

43 See, Socialist Turkey Party (STP), Case No.1993/2 (Political Party Dissolution), Decision No. 1993/3. 


\section{Deniz Polat}

Understanding of the Turkish Constitutional Court

legitimate, but converting these traditions into political claims should be considered as illegitimate ${ }^{44}$. To be clear about that, the TCC uses a rather literary and emotional statement: 'the State is single; the territory is a whole; the nation is one'45.

On the contrary to previous judgments, in 2008, the TCC refused to dissolve a political party - named HAK-PAR - which defended extensive cultural rights for the Kurdish minority ${ }^{46}$. HAK-PAR demanded the comprehensive devolution of power to local authorities, especially in the fields of education, health, local security, local taxes, and the popular election of governors, subgovernors, and local security chiefs. This time, the TCC determined that, as long as the statements of the party do not cause an 'open and present danger' for democratic life, they should be considered within the range of the freedom of expression ${ }^{47}$. This understanding may be seen in the DTP case as well. In this case, the Court set forth that the DTP violated the indivisible integrity of the state with its territory and nation and stressed that supporting violence or having an organic relationship with a terrorist organization, which would be regarded as legal grounds to ban a political party, and it ruled that the DTP should be dissolved based on these justifications ${ }^{48}$. These two judgments mean that peaceful demands for changing

44 Dicle Koğacioğlu, "Dissolution of Political Parties by the Constitutional Court in Turkey: Judicial Delimitation of the Political Domain", International Sociology, Vol. 18, No. 1, 2003, at 265.

45 See, Democracy Party (DEP), Decision No. 1994/2; Freedom and Democracy Party (OZDEP), Decision No. 1993/2; Socialist Party (SP), Decision 1992/1.

46 Rights and Freedoms Party (Hak-Par), Case No. 2002/1(Political Party Dissolution), Decision No. 2008/1 (TCC, 29.01.2008), published in Official Gazette 26923, 1.07.2008.

47 Rights and Freedoms Party (Hak-Par), Decision No. 2008/1.

48 See, Democratic Society Party (DTP), Case No. 2007/1 (Political Party Dissolution), Decision No. 2009/4 (TCC, 11 December 2009), published in Official Gazette 27432, 14 December 2009. The same legal ground is used by TCC in People's Democracy Party (HADEP) case and the Party was dissolved. See, People's Democracy Party (HADEP), Decision No. 2003/1. 
the unitary state type may be interpreted within the exercise of the freedom of expression or freedom of thought. The Court clearly noted that, only the statements in the statute and the program of the party would not be sufficient grounds in a democratic society to dissolve a political party, since the Constitution should be interpreted in order to obtain the compatibility with the standards of contemporary civilization 49 . Therefore, this should be followed by an analysis of the prohibition criteria developed by the European Court of Human Rights (ECHR) and the Venice Commission.

The ECHR states that unless a political party seeks to advocate violence, encourage violence, or use violence as a mean to overthrow the democratic constitutional order, it should be regarded as compatible with democratic principles. Indeed, Court's general jurisprudence is based on defending pluralism, since there can be no democracy without pluralism ${ }^{50}$. The ECHR previously concluded that one of the main characteristics of democracy is the possibility of resolving a country's problems through dialogue, without recourse to violence, even when they are irksome ${ }^{51}$. Then, suggestions and incredulous ideas, which include even changing the current government form or state type, should be regarded as the essentiality of democracy, as soon as no harm is done to democracy itself ${ }^{52}$. This is the reason why the

49 Rights and Freedoms Party (Hak-Par), Decision No. 2008/1; Democratic Society Party (DTP), Case No. 2007/1 (Political Party Dissolution), Decision No. 2009/4 (TCC, 11 December 2009), published in Official Gazette 27432, 14 December 2009.

50 Case of United Communist Party of Turkey and Others v. Turkey, App. Nos. 19392/92 (ECHR, 30.01.1998), para. 43.

51 Case of Freedom and Democracy Party v. Turkey, App. No. 23885/94 (ECHR, 8.12.1999), para. 44; Case of Socialist Party and Others v. Turkey, App. No. 21237/93 (ECHR, 25.05.1998), para. 45; Case of United Communist Party of Turkey and Others v. Turkey, para. 57; The Case of HADEP and Demir v. Turkey, App. No. 28003/03 (ECHR, 14.12.2010), para. 79.

52 See, Case of Socialist Party and Others v. Turkey, App. No. 21237/93 (ECHR, 25.05.1998), para. 46, 47; Case of United Communist Party of Turkey and Others v. Turkey, para. 57; Case of Freedom and Democracy Party v. Turkey, App. No. 23885/94 (ECHR, 8.12.1999), 


\section{Deniz Polat}

Understanding of the Turkish Constitutional Court

ECHR has consistently found a violation of the Convention in all cases of Turkey, except for the Welfare Party case ${ }^{53}$. In a similar way, the Venice Commission denotes that supporting terrorism or armed conflict, defending racism, and creating rancor and hostility in the society by these are reasons for banning a political party permanently ${ }^{54}$. However, trying to change the constitution in a democratic and peaceful way would not be enough justification for banning a political party ${ }^{55}$.

The TCC uses the article 90 (5) of the Constitution as the legal grounds and notes that the aim of this article is to establish the harmony between the legal order of the country and contemporary democracies ${ }^{56}$. In this respect, the Court tries to utilize the standards that were developed by the ECHR and the Venice Commission. Yet there appears to be a fundamental difference between these decisions of the Turkish Constitutional Court and those of the ECHR and the Venice Commission. Considering the majority of the judgments of the TCC, we may say that the Court makes good use of the European Convention of Human Rights and international standards, but only to justify its own, conflicting, 'ideology-based' rationale ${ }^{57}$. On the other hand, although in the past the Court dissolved the political

para. 41; The Case of Yazar, Karataş, Aksoy and The People's Labour Party v. Turkey, App. No. 22723/93, (ECHR, 9.04.2002).

53 See, Welfare Party and Others v. Turkey, App. No. 41340/98, 41342/98, 41344/98 (ECHR, 31.07.2001). Since the legal ground of this case is principle of secularism, it will be outside the framework of this article.

54 "Guidelines on Prohibiton and Dissolution of Political Parties and Analogous Measures", European Commission for Democracy Through Law-Venice Commission, CDL-INF (2000) 1, http://www.venice.coe.int/webforms/documents/default.aspx?pdffile $=$ CDL-INF $\% 282000 \% 29001-e$, Access Date: 20.08.2014.

55 See, supra note 54.

56 Article 90 (5) of the Constitution stipulates that, "in the case of a conflict between international agreements, duly put into effect, concerning fundamental rights and freedoms and the domestic laws, due to differences in provisions on the same matter, the provisions of international agreements shall prevail."

57 Esen, supra note 38, at 145; Özbudun, supra note 38, s. 125. 
parties only based on a statement against the principle of the unitary state, in the latest cases it searched for contemporary criteria - such as supporting violence. Regarding these latest judgments, one may say that the Court discontinues the 'unitary state centered' understanding. However, as of today, it's hard to clarify the up-to-date jurisprudence of the TCC, because of the insufficient research material at hand. Therefore, the other cases, which include the interpretation of unitary state of the TCC, should be considered.

As mentioned above, the review of the understanding of the Turkish Constitutional Court regarding the principle of the unitary state has been based on the political party dissolution cases. Nonetheless, the two cases against certain provisions of the "Law on Special Provincial Administration (Law No. 5302)" and the "Municipal Law (Law No. 5393)", which are considered as "Public Administration Reform", would be enlightening for understanding the latest interpretation of the Court on the unitary state issue.

In both of these annulment actions, the assertions were based on the unitary state type, the integrity of the administration, decentralization, and the administrative tutelage, which are stipulated by the Constitution. The Turkish Constitutional Court referred to the principle of the integrity of the administration, which was signified in the article 123 (1) of the Constitution, in both of the cases ${ }^{58}$ and stated that this integrity has always been a natural consequence of the unitary state. According to the Court, "the integrity of the administration is a fundamental administrative principle of the unitary state. This principle says that, several establishments, even if they are subject to different legal statuses and have administrative functions, all form a whole. The integrity of the administration may be enforced under the supervision and the control of the central administration; and to provide this integrity there should be three legal tools named,

58 According to the article 123 (1) of the Constitution; "the administration forms a whole, with regard to its constitution and functions, and shall be regulated by law." 


\section{Deniz Polat}

Understanding of the Turkish Constitutional Court

hierarchy, devolution of powers and administrative tutelage ${ }^{59}$. The TCC defends that, administrative tutelage prevents the potential differentiation and separation in the administrative system since it ensures the integration of the centralized and the decentralized administration bodies ${ }^{60}$. In other words, the Court sees the integrity of the administration and the administrative tutelage as inseparable components of the unitary state type.

The integrity of the administration and the principle of the unitary state are indeed attached to each other. Since there is only a single sovereignty in a unitary state, the authority of the state should be single as well. Accordingly, even if there are several public corporate bodies, the integrity of them constitutes the integrity of the administration ${ }^{61}$. With regard to this administrative integrity, the article 127 (1) of the Constitution stipulates that the decision-making organs of the local administrative bodies should be elected by the electorate, and these bodies should meet the common local needs of the inhabitants of provinces in accordance with the decentralization principles ${ }^{62}$. That is to say, the Constitution prescribed the administrative autonomy to meet these common local needs efficiently. Then, the administrative tutelage - which is defined as the recognized legal relationship between the central and the local administration bodies to obtain the integrity and the

59 Constitutional Court decision, E. 2005/32, K. 2007/3, 18 January 2007, Resmi Gazete (Official Gazette), 29 December 2007, no. 26741. Also see, Constitutional Court decision, E. 2013/19, K. 2013/100, 12 September 2013, Resmi Gazete (Official Gazette), 18 September 2014, no. 29123.

60 Constitutional Court decision, E. 2008/27, K. 2010/29, 4 February 2010, Resmi Gazete (Official Gazette), 21 June 2010, no. 27619.

61 Kemal Gözler, İdare Hukuku, Vol. 1, 2nd edition, Ekin 2009, at. 195; Metin Günday, İdare Hukuku, İmaj Yayınevi, Ankara 2013, at. 80.

62 See, the 1982 Constitution, article 127 (1). For a definition of the "local common needs", see, Constitutional Court decision, E. 1987/18, K. 1988/23, 22 June 1988, Resmi Gazete (Official Gazette), 26 November 1988, no. 20001 
efficiency of the administration - is not a rule but an exception to this administrative autonomy ${ }^{63}$.

In spite of this, the TCC does not interpret the administrative tutelage as an exception but as a mandatory constitutional authority of central administration to approve, refuse, and change the executive decisions of the local administrations, in order to protect the public interest ${ }^{64}$. The Court states that, even the administrative and the financial autonomy is recognized to the local administrative bodies; the control of the central administration over the local administrations has been prescribed since the 1924 Constitution as well65. According to the TCC, the purpose of regulating the administrative tutelage was to clarify that the local administrations have limited autonomy66. Therefore, any kind of restrictive regulation on the scope of the central authority would be regarded as the violation of the integrity of the administration and the unitary state type ${ }^{67}$. Considering these cases, it's clear that the TCC deals with the administrative tutelage or integrity of the administration within the context of the unitary state and objects to the reinforcing of regulations on the autonomy of local administrations. However, since the local administrative autonomy is envisaged in the Constitution, restrictions on the administrative tutelage, in the name of decentralization, would be compatible with the Constitution 68 .

The jurisprudence of the Turkish Constitutional Court based on the integrity of the administration and the unitary state is incompatible with the principles of the European Charter of Local Self-Government as well69. This Charter may be seen as one of the

63 Gözler, supra note 61, at. 208-210; Günday, supra note 61, at. 86.

64 See the Constitutional Court decision, supra note 59 and supra note 60. As well, see the Constitutional Court decision, 1990/38, K. 1991/32, 26 September 1991, Resmi Gazete (Official Gazette), 28 November 1991, no. 21065.

65 See the Constitutional Court decision, supra note 59 and supra note 60.

66 See, supra note 59 and supra note 60.

67 See, supra note 59 and supra note 60.

68 See the counter votes of the Constitutional Court decision, supra note 60.

69 European Charter of Local Self-Government, http://conventions.coe.int/ Treaty/en/Treaties/Html/122.htm; Access Date: 24.03.2015. For the 


\section{Deniz Polat}

Understanding of the Turkish Constitutional Court

very important standards regarding the definition and the scope of local administrative autonomy. The Republic of Turkey signed the Charter in 1988, approved it in 1992, and it took effect in 1993. Based on the article 90 (5) of the Constitution, the Charter duly was put into effect and has the force of law ${ }^{70}$. The aim of the Charter is to ensure the adoption of the principles of the democratic local administration by member states. One of the most basic principles envisaged by the Charter is the "subsidiarity principle", and it's regulated in article 4 as, "public responsibilities shall generally be exercised, in preference, by those authorities which are closest to the citizen"11. We may say that the Turkish Constitutional Court disregards these principles of the Charter in its judgments. Although the Charter prescribes that "local authorities shall be entitled, within national economic policy, to adequate financial resources of their own, of which they may dispose freely within the framework of their powers ${ }^{72}$ ", the TCC sees the central administration body as the single authority in the administration field. In an action for annulment based on the assertions that a proportional income should be determined to

decision and the recommendation of the Congress of Local and Regional Authorities of the Council of Europe, 20 th Session, CG(20)6, 1 March 2011, "Local and regional democracy in Turkey" see, https://wcd.coe.int/ViewDoc.jsp?id=1754625\&Site=COE\#P46_1375;

Access Date: 24.03.2015. The Congress states that, progress towards the reforms has been particularly slow. It is recommended that Turkey should continue the monitoring of obligations according to the European Charter of Local Self-Government and accelerate the process of constitutional reforms towards decentralization, notably by removing administrative tutelage.

70 According to the article 90 (5) of the 1982 Constitution; "International agreements duly put into effect have the force of law. No appeal to the Constitutional Court shall be made with regard to these agreements, on the grounds that they are unconstitutional. (Sentence added on May 7, 2004; Act No. 5170) In the case of a conflict between international agreements, duly put into effect, concerning fundamental rights and freedoms and the laws due to differences in provisions on the same matter, the provisions of international agreements shall prevail."

71 European Charter of Local Self-Government, art. 4 (3).

72 European Charter of Local Self-Government, art. 9 (1). 
local administration bodies in accordance with their jurisdiction, the Court neglected the Charter and stressed that the local administrations should not have a certain financial autonomy ${ }^{73}$.

As a matter of fact, based on the Constitution, the Charter neither has the equal force of the Constitution nor is it above it. Then, the TCC may not take the Charter into consideration, firstly and directly. However, based on the article 90 (5) of the Constitution, the Court could have preferred to interpret the Constitution in accordance with the tendency to the democratic local administrations, but it did not. Since the 1982 Constitution regards the administrative tutelage as an exception, restriction of this principle in the name of "subsidiarity" would be considered as constitutional. Instead of this, the Court gave preference to the principle of the unitary state and missed a chance to harmonize the Constitution with the international democratic principles as yet.

In addition to these, even if we accept the fact that the administrative regulations restrict the power of the central administration, this may not mean the violation of territorial and national integrity of the state, in other words, the unitary state type $^{74}$. The reason is that the difference is between the integrity/unity of the state and the integrity of the administration. They surely are related to each other, but as long as the central administration keeps the legislative authority, other regulations regarding the administrative autonomy would not violate the principle of the unitary state ${ }^{75}$. Having an administrative or a financial autonomy as a local administration would be different from being independent. In fact, these administrative or financial autonomies should be recognized in order to solve the regional problems of the local population

73 Constitutional Court decision, E. 2003/86, K. 2004/6, 28 January 2004, Resmi Gazete (Official Gazette), 6 November 2004, no. 25635.

74 Metin Günday, "Kamu Yönetimi Reformunun İdari Yapılanmaya İlişkin Anayasal İlkeler Açısından Değerlendirilmesi (The Review of the Public Administration Reform With Regards to the Constitutional Principles of Administration)", Symposium of the Year 137 of the Council of State, Danıştay Yayınlanı, Ankara, 11 May 2005, at 99.

75 Günday, supra note 74, at. 100. 


\section{Deniz Polat}

Understanding of the Turkish Constitutional Court

efficiently and immediately, with the aim of the public interest. It seems that the TCC does not share the same opinion.

\section{Conclusion}

We may criticize the interpretation of the Turkish Constitutional Court regarding the unitary state on several grounds. First of all, the Court deals with the principle of the indivisible integrity of the state with its territory and nation' as it is synonymous with the unitary state type. Secondly, this interpretation tends to undermine the pluralistic worldview which dominates the modern democracies. The TCC considers the demands for a different state type as racism and classifies them as irrelevant to political or/and democratic rights. This understanding as the essential legal ground of the TCC is incompatible with the principles that are set forth by the European Court of Human Rights and the Venice Commission as well.

The Court left a strongly-worded description of this principle both in the political party dissolution cases and in the annulment actions - and continues to interpret the territorial and the national integrity of the state as a historically indispensable fundamental element ${ }^{76}$. In other words, historical fear for division of the state may be easily observed in these judgments and seems that the integrity of the state generally has the priority ${ }^{77}$. Therefore, this attitude of the Turkish Constitutional Court may be seen as contrary to the multi-party democracy or to the principles of democratic local administration.

However, there has not been an action for a party dissolution in Turkey since the last party dissolved in 2009. Moreover, the last case regarding the unitary state was in 2010 and after this, the TCC did not have a chance to interpret this principle again. Then, we may conclude that even if the Turkish Constitutional Court's

76 Esen, supra note 38, at 151.

77 İbrahim Kaboğlu, "İfade Özgürlügünün Siyasi Partilerce Kullanımının Sinırlar1 (Limits of Political Parties in Exercising the Freedom of Expression)", Anayasa Yargisı, C. 16, Anayasa Mahkemesi Yayınları, Ankara 1999, at 87. 
jurisprudence so far signifies a rigid perspective, it is hardly possible to foresee whether or not the Court is changing this understanding of the unitary state. 